\title{
Șiddetli Postmenopozal Osteoporozlu Hastalarda Teriparatid Tedavisinin Ağrı, Yașam Kalitesi, Depresyon ve Biyokimyasal Parametreler Üzerine Etkisi: Erken Dönem Sonuçlar
}

\author{
The Effects of Teriparatide Treatment on Back Pain, Quality of Life, Depression and Biochemistry \\ Parameters in Patients with Severe Postmenopausal Osteoporosis: Short-Term Results
}

\author{
Yeşim AKYOL, Ayşegül ATMACA*, Dilek DURMUŞ, Yasemin ULUS, Berna TANDER, Gamze ALAYLI \\ Ondokuz Mayıs Üniversitesi Tıp Fakültesi, Fiziksel Tıp ve Rehabilitasyon Anabilim Dalı, Samsun, Türkiye \\ *Ondokuz Mayıs Üniversitesi Tıp Fakültesi, Endokrinoloji ve Metabolizma Bilim Dalı, Samsun, Türkiye
}

\section{Özet}

Amaç: Bu çalışmanın amacı, şiddetli postmenopozal osteoporoz (OP) olan hastalarda teriparatid tedavisinin sırt ağrısı, yaşam kalitesi, depresyon ve biyokimyasal parametreler üzerine erken dönemdeki etkisini belirlemektir.

Gereç ve Yöntem: Çalışmaya şiddetli OP tanısı konan 21 postmenopozal kadın hasta alındı. Hastalara altı ay süre ile subkutan $20 \mu \mathrm{q} /$ gün teriparatid tedavisi ve $800 \mathrm{IU} / g u ̈ n$ D3 vitamini $+1,200 \mathrm{mg} / \mathrm{gün}$ kalsiyum verildi. Hastalar tedavi öncesi ve sonrasında vizüel analog skala (VAS), Avrupa Osteoporoz Vakfı Yaşam Kalitesi Anketi (OUALEFFO), Beck Depresyon Ölçeği (BDÖ) ve biyokimya parametreleri (serum kalsiyum, fosfor, ürik asit, alkalen fosfotaz, PTH, 25-OH vitamin D3, böbrek ve karaciğer fonksiyon testleri) ile değerlendirildi.

Bulgular: Sekiz hasta teriparatid tedavisini maliyet ve/veya kullanım zorluğu nedeni ile keser iken, 13 hasta tedaviyi tamamladı. Tedaviyi tamamlayan hastaların tedavi öncesi ve sonrası değerleri karşılaştıııldığında, tedavi sonrası VAS ağrı, QUALEFFO ağrı alt parametresi ve total skoru açısından istatistiksel olarak anlamlı iyileşme saptandı $(p<0,05)$. BDÖ skoru ve biyokimya parametreleri açısından istatistiksel olarak anlamlı fark bulunmadı $(p>0,05)$.

Sonuç: Şiddetli OP'si olan postmenopozal hastalarda teriparatid tedavisi erken dönemde sırt ağrısı ve yaşam kalitesi üzerine etkili olup, bu hastalarda önemli bir tedavi seçeneği olabilir. Türk Fiz Tıp Rehab Derg 2011;57:134-8. Anahtar Kelimeler: Şiddetli postmenopozal osteoporoz, teriparatid tedavisi

\section{Summary}

Objective: The aim of this trial was to determine the early effects of teriparatide treatment on back pain, quality of life, depression, and biochemical parameters in patients with severe postmenopausal osteoporosis (OP).

Materials and Methods: Twenty-one female patients with severe postmenopausal OP were included in this study. The patients received daily doses of $20 \mu \mathrm{g}$ of teriparatide and $800 \mathrm{IU}$ vitamin D3 $+1.200 \mathrm{mg}$ calcium for a period of six months. The subjects were evaluated on the basis of the visual analogue scale (VAS), Quality of life Questionnaire of the European Foundation for Osteoporosis (QUALEFFO), the Beck Depression Scale (BDS) and biochemical parameters (serum calcium, phosphorus, uric acid, alkaline phosphatase, parathyroid hormone, 25-OH vitamin D3, kidney and liver function tests) before and after treatment.

Results: Eight patients discontinued teriparatide treatment because of high cost and/or difficulties in application. Thirteen patients who continued the teriparatide treatment demonstrated statistically significant improvements on the pain VAS and the QUALEFFO (subgroups of pain and total scores) after therapy compared with baseline $(p<0.05)$. There was no statistically significant difference in both BDS scores and biochemical parameters ( $p>0.05)$. Conclusion: In patients with severe postmenopausal OP, teriparatide therapy is effective in reducing back pain and improving quality of life in the short term and can be considered as an important treatment choice for these patients. Turk J Phys Med Rehab 2011;57:134-8.

Key Words: Severe postmenopausal osteoporosis, teriparatide treatment 


\section{Giriş}

Osteoporoz (OP) ve osteoporoza bağlı gelişen kırıklar günümüzde morbidite, mortalite ve maliyet açısından özellikle de menopoz sonrası kadınlarda en önemli sağlık sorunudur. Artmış kemik kırılganlığı nedeni ile tüm kemikler için kırık riski olmakla birlikte osteoporotik kırıklar en çok kalça, vertebra ve el bileğinde görülürler (1). Osteoporotik kırıklar ağrı, fiziksel fonksiyon, sosyal fonksiyon ve iyilik halinde azalma, depresyon ile ilişkili olduğundan ve tüm bunlar yaşam kalitesini belirlediğinden osteoporozda yaşam kalitesi olumsuz etkilenmektedir $(2,3)$.

OP tedavisini planlarken kemik kütlesini korumak, ağrıyı ve yeni kırık insidansını azaltmak esasdır (4). Bu amaçla osteoklastik aktiviteyi azaltmak suretiyle etki gösteren çeşitli antirezorptif ilaçlar yaygın olarak kullanılmaktadır (5). Son yıllarda ise OP tedavisinde kemik yapımını arttıran ajanlar ağırlık kazanmaya başlamıştır. Bunlar arasında özellikle paratiroid hormon (PTH) öne çıkmaktadır. Paratiroid hormonun kemik üzerine etkisi çok karmaşıtır. Yüksek PTH düzeylerinin özellikle kortikal kemikte katabolik etkisi ve kemik mineral yoğunluğu (KMY)'nu azalttığı bilinmektedir. Ancak düşük dozlarda intermittan uygulanması osteoblast sayı ve aktivitesinde artışa neden olarak KMY'yi artırmaktadır (6-8). PTH tedavisi alan hastaların kemik biyopsilerinden elde edilen bulgular, PTH'nın yeniden şekillenmeyi (remodeling) uyardığını ve yeni oluşmuş matriksin oranını arttırdığını, ancak bu matriksin mineral yoğunluğunun daha düşük olduğu şeklindedir. Bu durum PTH ile birlikte kalsiyum ve D vitamini eklerinin de kullanılması gerektiğini göstermektedir (9). Teriparatid rekombinant insan PTH (1-34) fragmanı olup, kırık için yüksek riskli olan veya daha önceki OP tedavilerine yanıt vermemiş olan ya da bunları tolere edemeyen idiyopatik veya hipogonadal OP'li erkeklerde ve postmenopozal kadınlarda tedavi için FDA onayı almıştır. Kullanım şekli ve önerilen dozu $20 \mu \mathrm{g}$ /gün subkutan enjeksiyon şeklindedir (10).

Teriparatid'in ülkemizde klinik pratikte kullanımı henüz yaygınlaşmamış olup, etkinliğine ilişkin çalışma ve klinik gözlemler oldukça sınırııdır. Bu çalışmanın amacı şiddetli postmenopozal OP'si olan hastalarda teriparatid tedavisinin sırt ağrısı, yaşam kalitesi, depresyon ve biyokimyasal parametreler üzerine erken dönemdeki etkisini belirlemektir.

\section{Gereç ve Yöntem}

Retrospektif olan çalışmaya, Ondokuz Mayıs Üniversitesi Fiziksel Tıp ve Rehabilitasyon Anabilim Dalı Osteoporoz Polikliniği'ne Kasım 2008-Şubat 2010 tarihleri arasında başvuran, yerleşmiş-şiddetli OP tanısı konmuş ve teriparatid tedavisi başlanmış postmenopozal kadın hastalar dahil edildi. Katılımcılar çalışma hakkında bilgilendirildi ve sözlü onamları alındı. Çalışma Helsinki Bildirgesine uygun olarak yürütüldü. Hastaların dosyalarından yaş (yıl), boy (cm), kilo $(\mathrm{kg})$, vücut kitle indeksi (VKI, kg/m), menopoz süresi (yıl), OP tanı süresi (yıl), eğitim düzeyi, mesleki durumu, çocuk sayısı, eşlik eden hastalıkları, OP risk faktörleri kaydedildi. Yerleşmiş OP tanısı klinik değerlendirme, lateral spinal grafi, lomber ve femur kemik mineral yoğunluğu (KMY) değerleri ve laboratuvar bulgularına göre konuldu. KMY Dual Enerji X-ışını Absorbsiyometri (DXA) yöntemi kullanılarak (Norland Excel, USA) lomber bölge ve proksimal femurdan ölçüldü. Torakal ve lomber vertebraların ön, orta, arka yükseklikleri ölçüldü ve bir vertebranın üç yükseklik ölçümünden en az biri en yakın normal vertebranın yükseklik ölçümünden $\% 20$ azalmış ise bu kırık olarak kabul edildi (11). Yerleşmiş OP tanısı Dünya sağlık örgütü sınıflan- masına göre (T skoru <-2,5 olmasına ek olarak bir veya daha fazla kırık saptanması) tanımlandı (12). Lomber veya femur total T skoru 4 ve daha az olan, grafisinde en az 2 vertebra kırı̆̆ tespit edilen hastalar şiddetli OP olarak kabul edildi. Kemik ve kalsiyum metabolizmasını etkileyebilecek OP dışında hastalığı olanlar (osteomalazi, Paget hastalığı, hipertiroidi, hiperparatiroidi, kronik böbrek ve karaciğer yetmezliği, malabsorbsiyon, malignensi vb.) ve ilaç kullanımı olan hastalar (kortikosteroid, antikonvülzan, tiroid hormonu, antiasit, antikoagülan, kemoterapötikler vb.) ile antidepresan tedavi alan hastalar çalışma dışı bırakıldı. Hastalar analjezik amaçlı ve komorbid hastalıkları için kullanmakta oldukları ilaçlara devam ettiler.

Hastalar altı ay süre ile subkutan $20 \mu \mathrm{g} /$ gün teriparatid ve ek olarak 800 IU/gün D3 vitamini, 1,200 mg/gün kalsiyum tedavisi almıştı.

Hastaların dosyalarından tedavi öncesi (TÖ) ve tedavinin 6. ayında (TS) olmak üzere iki kez değerlendirilen sırt ağrısı şiddeti, yaşam kalitesi ve depresyon düzeyi ve biyokimya parametrelerinden; kalsiyum (Ca), fosfor (P), alkalen fosfotaz (ALF), PTH, 25$\mathrm{OH}$ vitamin D3, üre, kreatinin, aspartat aminotransferaz (AST), alanin aminotransferaz (ALT) ve ürik asit düzeyleri kaydedildi.

Klinik değerlendirme için kullanılan ölçekler:

\section{Sırt Ağrı Düzeyi}

Vizüel analog skala (VAS) ile değerlendirildi. Hastalara 10 cm'lik bir hat üzerinde rakamların her birinin ne anlama geldiği anlatılarak, günlük aktiviteleri esnasındaki sırt ağrısının şiddetini işaretlemeleri istendi. Hiç ağrının olmaması 0, orta derecede ağrı 5, hayatta hissedilen en şiddetli ağrı 10 puan olarak açıklandı.

\section{Yaşam kalitesi}

Türk toplumu için adaptasyonu yapılmış, geçerliliği ve güvenilirliği kanıtlanmış olan OUALEFFO (Quality of life Questionnaire of the European Foundation For Osteoporosis) kullanılarak değerlendirildi (13). Bu anket ağrı (5 soru), fiziksel fonksiyon (17 soru), sosyal fonksiyon (7 soru), genel sağlık değerlendirmesi (3 soru) ve mental fonksiyon (9 soru) alt skalalarında toplam 41 sorudan oluşmaktadır. Total skor ve alt skala skorları için 0 iyi sağlık durumunu, 100 ise kötü sağlık durumunu göstermektedir.

\section{Depresyon}

Beck Depresyon Ölçeği (BDÖ) ile değerlendirildi. Anket şeklinde düzenlenen ve 21 sorudan oluşan bu ölçekte, hastalardan kendilerine en uygun olan cümleyi seçmeleri istendi (14). Her madde 4 cümleden oluşmaktaydı. Bu cümleler, nötral durumdan (0 puan), en ağır duruma (3 puan) göre sıralanmıştı. Bu ölçeği oluşturan cümleler tedaviye alınan depresyon hastalarının ifadelerinden oluşturulmuştur. En yüksek puan 63'tür. 0-13 puan arası depresyon yok, 14-24 puan arası orta derecede depresyon, 25 puanın üzeri ciddi depresyon olarak değerlendirildi.

Hastalara bu ölçüm yöntemleri, tedavi öncesi ve tedavinin 6. ayında osteoporoz polikliniği doktoru tarafından uygulandı. Yapılan taramada teriparatid tedavisi başlanan 21 hasta olduğu, bunlardan sekizinin altı aylık tedaviyi tamamlamadığı saptandı. Altı aylık tedaviyi tamamlayan 13 hastanın verileri üzerinden istatistiksel analiz yapıldı.

İstatistiksel analizler için SPSS 15.0 Windows paket programı kullanıldı. Yaş, boy, kilo, menopoz süresi, OP tanı süresi, mesleki durum, eğitim durumu, çocuk sayısı gibi sosyo-demografik veriler için betimsel istatistik ve frekans analizi yapıldı. Verilerin normal dağılıma uyup uymadığı Shapiro-Wilk testi ile değerlendirildi. Değerler normal dağılıma uyduğundan, tanımlayıcı istatistikler için ortalama \pm standart sapma kullanıldı. Değişkenlerin tedavi öncesi ve sonrası değerlerinin karşılaştırılmasında Paired t testi kullanıldı. p değeri $<0,05$ ise anlamlı kabul edildi. 
Tablo 1. Hastaların sosyo-demografik özellikleri ve klinik bulguları.

\begin{tabular}{|c|c|c|}
\hline \multicolumn{3}{|l|}{ Özellikler } \\
\hline & Ortn (min ; max) & Ort. $\pm S S$ \\
\hline Yaş (yıl) & $76(66 ; 81)$ & $73,67 \pm 4,50$ \\
\hline Boy $(\mathrm{cm})$ & $154(140 ; 166)$ & $153,62 \pm 7,86$ \\
\hline Kilo (kg) & $56(40 ; 85)$ & $57,86 \pm 13,73$ \\
\hline VKi $\left(\mathrm{kg} / \mathrm{m}^{2}\right)$ & $23(17 ; 37)$ & $24,46 \pm 5,40$ \\
\hline Menopoz süresi (yıl) & $29(18 ; 45)$ & $29,66 \pm 6,49$ \\
\hline OP tanı süresi (yıl) & $2(0 ; 7)$ & $2,28 \pm 2,17$ \\
\hline Kırık vertebra sayısı & $2(2 ; 12)$ & $3,71 \pm 2,77$ \\
\hline Lomber (1-4 vertebra) T skoru & $-4,8(-6 ;-0,78)$ & $-4,68 \pm 1,04$ \\
\hline \multirow[t]{2}{*}{ Femur total T skoru } & $-3(-5,8 ; 0,37)$ & $-3,07 \pm 1,48$ \\
\hline & $\mathrm{n}$ & $(\%)$ \\
\hline $\begin{array}{l}\text { Eğitim Düzeyi } \\
\text { Okur yazar değil } \\
\text { Illkokul }\end{array}$ & $\begin{array}{c}18 \\
3 \\
\end{array}$ & $\begin{array}{l}(85,7) \\
(14,3) \\
\end{array}$ \\
\hline \multicolumn{2}{|l|}{ Mesleki durumu } & $(100)$ \\
\hline $\begin{array}{l}\text { Çocuk sayısı } \\
\qquad \begin{array}{l}1 \\
3 \\
4 \\
5 \text { ve üstü }\end{array}\end{array}$ & $\begin{array}{c}1 \\
5 \\
4 \\
11\end{array}$ & $\begin{array}{c}(4,8) \\
(23,8) \\
(19) \\
(52,4)\end{array}$ \\
\hline $\begin{array}{l}\text { Ortn (min; max): Ortanca (minimur } \\
\text { Sapma }\end{array}$ & aksimum), Ort. \pm SS & rtalama \pm Standart \\
\hline
\end{tabular}

\section{Bulgular}

Hastaların sosyo-demografik özellikleri Tablo 1'de gösterilmiştir.

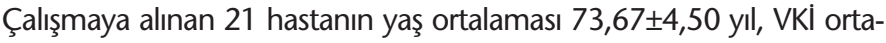
laması $24,46 \pm 5,40 \mathrm{~kg} / \mathrm{m}^{2}$ idi. Lomber (L1-4) vertebra ve femur total T skoru ortalaması sırası ile $-4,68 \pm 1,04$ ve $-3,07 \pm 1,48$ olarak saptandı.

Sekiz hastanın ilk altı ay içerisinde teriparatid tedavisini sonlandırdığı belirlendi. Tedaviyi kesme nedenini; 4 hasta kullanım zorluğu, 1 hasta tedavi maliyetinin fazla oluşu, 3 hasta ise hem kullanım zorluğu hem de tedavi maliyetinin fazla oluşu şeklinde belirtmişti. Onüç hasta teriparatid tedavisine altı ay süre ile devam etmişlerdi (Şekil 1).

Tedavi öncesi ve sonrası değerler karşılaştırıldığında, VAS ağrı, QUALEFFO-ölçeği ağrı alt parametresi ve total skoru açısından istatistiksel olarak anlamlı fark saptandı $(p<0,05)$. Ancak BDÖ skoru ve biyokimya parametreleri (Ca, P, PTH, ALF, 25-OH vitamin D3, AST, ALT üre, kreatin, ürik asit) açısından istatistiksel olarak anlamlı fark bulunmadı ( $p>0,05)$ (Tablo 2).

Hastaların tedavi öncesi ve sonrası 25-OH vitamin D3 düzeyleri ortalamasının laboratuvar normal referans değerinden düşük, diğer biyokimyasal parametrelerin ortalamasının ise normal referans aralığında olduğu saptandı (Tablo2).

\section{Tartışma}

Osteoporoz gerek ağrı, gerek fiziksel fonksiyonlarda ve mobilitede azalmaya bağlı olarak yaşam kalitesini olumsuz etkilemektedir. Özellikle vertebral kırığı olan hastalarda yaşam kalitesi belirgin olarak bozulmaktadır. Osteoporoz hastalarında yaşam kalitesinin değerlendirilmesi, günümüzde sayısı giderek aratan çeşitli ilaç

Tablo 2. Hastaların klinik parametrelerinin tedavi öncesi ve sonrası değerlerinin karşılaştırılması.

\begin{tabular}{|c|c|c|c|c|}
\hline $\begin{array}{l}\mathrm{N}=13 \\
\text { Özellikler }\end{array}$ & & $\begin{array}{c}\text { TÖ } \\
\text { Ort. } \pm S S\end{array}$ & $\begin{array}{c}\text { TS } \\
\text { Ort. } \pm S S\end{array}$ & $\mathbf{P}$ \\
\hline VAS Ağrı & & $6,00 \pm 2,16$ & $4,54 \pm 2,25$ & 0,02 \\
\hline \multicolumn{5}{|c|}{ Biyokimya parametreleri (Normal referanslar) } \\
\hline Kalsiyum & $(8,1-10,7 \mathrm{mg} / \mathrm{dl})$ & $9,47 \pm 0,54$ & $9,66 \pm 0.60$ & 0,34 \\
\hline Paratiroid hormon & $(9-78 \mathrm{pq} / \mathrm{ml})$ & $72,19 \pm 35,48$ & $67,11 \pm 64,72$ & 0,65 \\
\hline 25-OH vitamin D3 & $(30-80 \mu \mathrm{g} / \mathrm{L})$ & $24,47 \pm 14,35$ & $26,45 \pm 25,59$ & 0,77 \\
\hline Üre & $(5-24 \mathrm{mg} / \mathrm{dl})$ & $22,39 \pm 9,31$ & $22,22 \pm 8,27$ & 0,91 \\
\hline Kreatin & $(0,4-1,4 \mathrm{mg} / \mathrm{dl})$ & $0,67 \pm 0,11$ & $0,74 \pm 0,14$ & 0,09 \\
\hline AST & $(8-46 \mathrm{U} / \mathrm{L})$ & $19,49 \pm 4,30$ & $21,86 \pm 5,54$ & 0,15 \\
\hline Ağrı & & $16,15 \pm 3,99$ & $11,77 \pm 5,68$ & 0,007 \\
\hline Fiziksel fonksiyon & & $42,85 \pm 9,45$ & $38,54 \pm 9,51$ & 0,08 \\
\hline Sosyal fonksiyon & & $15,46 \pm 4,80$ & $14,54 \pm 4,55$ & 0,15 \\
\hline Genel sağlık & & $11,46 \pm 2,87$ & $10,85 \pm 2,70$ & 0,28 \\
\hline Mental sağlık & & $28,69 \pm 6,43$ & $27,15 \pm 7,94$ & 0,19 \\
\hline Toplam skor & & $118,15 \pm 21,31$ & $105,69 \pm 24,49$ & 0,01 \\
\hline
\end{tabular}


tedavilerinin fonksiyonel durum veya yaşam kalitesi üzerindeki etkilerinin ortaya konmasında önemlidir (15-17).

Son yıllarda OP tedavisinde kemik yapımını artıran ajanlar ağırlık kazanmış, bunlar arasında özellikle teriparatid öne çıkmıştır $(18,19)$. Ancak ülkemizde OP tedavisinde teriparatid kullanımı henüz oldukça sınırlı olup, kullanımı, yan etkileri, tedavi sonuçları konusunda yeterli klinik deneyim ve dolayısı ile çalışma bulunmamaktadır. Bu çalışmada, şiddetli postmenopozal OP'si olan hastalarda teriparatid tedavisinin sırt ağrısı, yaşam kalitesi, depresyon ve biyokimyasal parametreler üzerine erken dönemdeki etkisi araştırıldı. Altı ay süre ile teriparatid tedavisi alan hastalarda, sırt ağrı düzeyi, yaşam kalitesi ağrı alt parametresi ve total yaşam kalitesi skoru açısından iyileşme saptanır iken, depresyon düzeyi ve biyokimya parametreleri açısından anlamlı bir değişiklik olmadığı gözlendi.

Nau ve ark. (20) tarafından yapılan retrospektif çalışmada, ortalama yaşları 63,8 yıl olan 47'si kadın 57 osteoporoz hastasında teriparatid tedavisinin yaşam kalitesi üzerine etkisi araştırılmıştır. Hastalar tedavinin 3. ve 6. ayında uygulanan semptom (ağrıya yönelik), fiziksel fonksiyon, emosyonel fonksiyon, günlük yaşam aktivitesi ve boş zaman aktivitesinin değerlendirildiği toplam 10 sorudan oluşan mini osteoporoz yaşam kalitesi anketi (OQLQ) ile değerlendirilmiştir. Semptom (ağrı), emosyonel fonksiyon ve boş zaman aktivitelerinde tedavinin 3. ayında, günlük yaşam aktivitelerinde ise 6. ayında iyileşme saptanır iken, fiziksel fonksiyonlarında her iki kontrolde de anlamlı iyileşme olmadığı raporlanmıştır. Langdahl ve ark. (21) tarafından 8 Avrupa ülkesini kapsayan çok merkezli EFOS çalışmasında 1,648 postmenopozal osteoporozu olan kadında 18 ay süre ile uygulanan teriparatid tedavisinin etkinliği araştırılmıştır. Çalışmada hastaların 3, 6, 12 ve 18. ay kontrollerinde vertebra ve nonvertebra frajilite kırığı insidansı, sırt ağrısı (VAS ve EFOS spesifik sırt ağrısı anketi), yaşam kalitesi parametreleri (European Quality of Life Questionnaire, EQ-5D) değerlendiril-

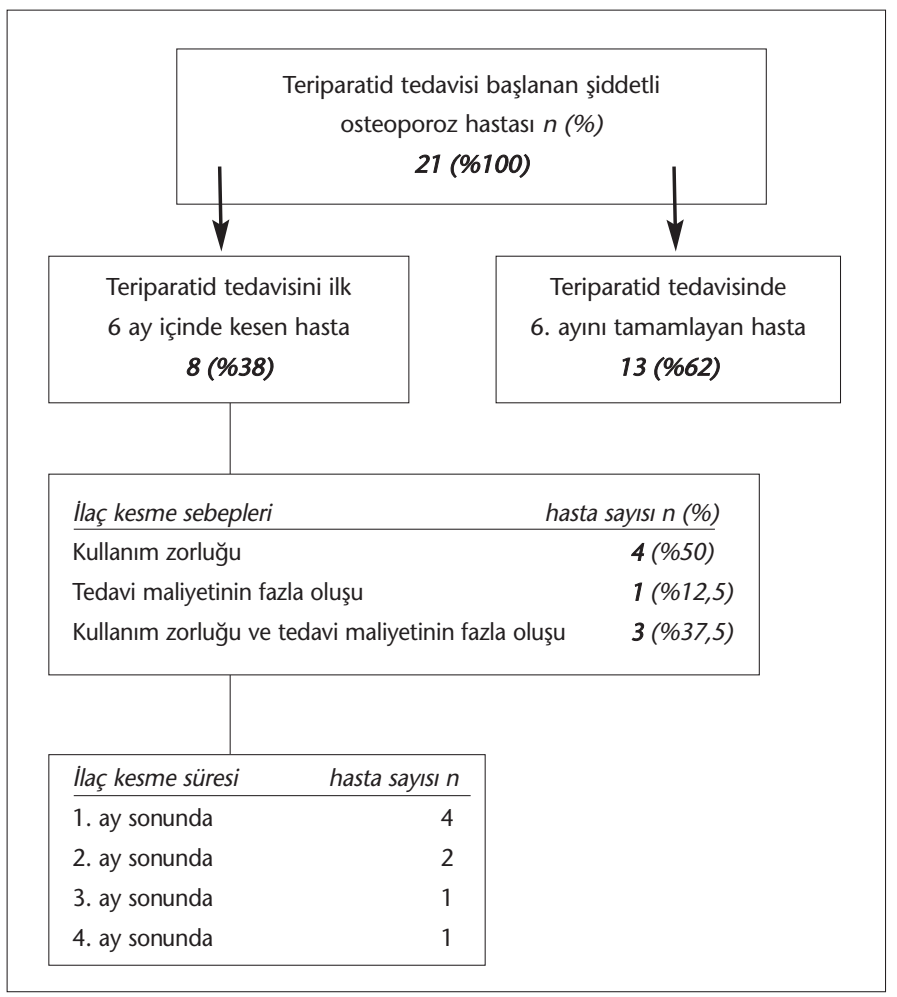

Şekil 1. Teriparatid tedavisi alan hastaların ilaç kullanımına uyumu. miştir. Yaşam kalitesi ve ağrı düzeylerinde üçüncü ayda başlamak üzere, yapılan tüm kontrollerde belirgin iyileşme saptandığı, frajilite kırığı insidansının ise ilk altı ay'dan itibaren giderek azaldığı belirtilmektedir. Yaşam kalitesindeki düzelmenin özellikle günlük aktivite ve ağrı alt parametrelerinde olduğu rapor edilmektedir. Bu çalışmada EFOS çalışmasına benzer şekilde teriparatid tedavisinin 6. ayında hastaların sırt ağrısı düzeyinde iyileşme ve yaşam kalitesi her ne kadar EFOS çalışmasından farklı bir ölçek ile (QUALEFFO) değerlendirilmiş olsa da, yaşam kalitesi total skoru ve ağrı alt parametresinde iyileşme tespit edilmiştir.

Literatürde teriparatid tedavisinin sırt ağrısı üzerine etkisinin değerlendirildiği ve bu çalışmanın sonuçlarıyla uyumlu olan başka çalışmalar da bulunmaktadır. Genant ve ark. (22) tarafından postmenopozal OP'li kadınlarda teriparatid tedavisi ile vertebra fraktürüne bağlı orta veya şiddetli sırt ağrısı insidansının azaldığı gösterilmiştir. Newitt ve ark (23) tarafından 2006 yılında yayınlanan dört çalışmanın değerlendirildiği (24-27) metaanalizde, teriparatid tedavisi ile plasebo veya antirezorptif ilaçlara kıyasla, tedavi sırasında ve sonrasındaki 30 aylık gözlem döneminde sırt ağrısı insidansının azaldığı belirtilmektedir.

Teriparatid tedavisi alan hastaların \%1-3'ünde ılımlı hiperkalsemi, ayrıca hiperürisemi, baş dönmesi, başağrısı, bulantı, bacak krampları gibi yan etkiler olabileceği bilinmektedir $(24,28,29)$. EFOS çalışmasının 6. ay kontrolünde çalışmadan ayrılma oranı \%12,3 olup, ayrılma nedeni olarak ilaç yan etkileri, hasta kararı ve hekim kararı olarak belirtilmiştir (21). Tedavi esnasında en sık görülen yan etkiler bulantı, baş ağrısı, yorgunluk ve depresyon şeklinde raporlanmıştır. Bizim çalışmamızda hastaların \%38'i teriparatid tedavisini sonlandırdı. Hastalar tedaviyi bırakma nedeni olarak ilacın kullanım zorluğu ve/veya tedavi maliyeti olarak bildirmişlerdi. Hiçbir hasta tedaviyi kesme nedeni olarak ilaç yan etkisini belirtmediği gibi, tedaviye devam edenler arasında EFOS çalışmasında belirtilen yan etkilerin hiçbiri tespit edilmedi.

Neer ve ark. (24) tarafından yapılan çalışmada $20 \mu \mathrm{q} /$ gün uygulanan teriparatid tedavisi ile serum $25(\mathrm{OH})$ vitamin D ve kalsitriol düzeylerinde tedavi öncesi değerlere göre artış olduğu, serum kreatinin konsantrasyonunun ise değişmediği raporlanmıştır. Aynı çalışmada serum Ca ve ürik asit konsantrasyonu artış gösterse de ortalama 5 hafta sonra tedavi öncesi değerlere geri döndüğü belirtilmiştir. Orwoll ve ark (25) tarafından yapılan çalışmada teriparatid tedavisi alan hastalarda serum kalsitriol düzeyinin tedavinin 1. ayında pik yaptığı ve çalışma boyunca normal seviyenin üstünde seyrettiği, serum Ca düzeyinin bir miktar yüksek seyretse de üst sınırı aşmadığı raporlanmıştır. Serum ürik asit düzeyinin ise uygulanan teriparatid dozu ile ilişkili olduğu, $20 \mu \mathrm{q} /$ gün dozunda değişmez iken, $40 \mu \mathrm{q} / g u ̈ n$ dozunda normal seviyenin üstünde olduğu belirtilmiştir. Serum intakt PTH düzeyi çalışma boyunca alt sınırın aşağısında seyretmiştir. Çalışmamızda hastaların tedavi öncesi ve sonrası 25-OH vitamin D3 düzeyi normalden düşük, diğer biyokimya parametreleri (Ca, P, ALF, PTH, AST, ALT, ürik asit, üre, kreatin) ise normal sınırlarda gözlendi. Biyokimya parametrelerinin tedavi öncesi ve sonrası değerleri karşılaştıııldığında ise anlamlı fark saptanmadı.

Osteoporoz kronik bir hastalıktır. Kronik hastalıkların depresyona neden olduğu bilinmektedir (30-32). Osteoporozda hastaların günlük rutin aktivitelerini yapmakta güçlük çekmesi, fonksiyonelliğin azalması ve bunun sonucunda kendini güvensiz ve işe yaramaz hissetmesi, zamanla sosyal aktivitelere katılma, ziyaret ve hobiler- 
de kısıtlanma sonucunda sosyal izolasyon, depresyon ve anksiyete gelişmesi olabilir (33). Bu nedenle OP'ye yönelik tedavi etkinliklerinin değerlendirildiği çalışmalarda hastaların ruhsal durumları sorgulanmaktadır (34). Literatürde teriparatid tedavisinin depresyon düzeyi üzerine etkisinin değerlendirildiği bir çalışmaya rastlanmamıştır. Bu çalışmada, tedavi öncesi ve sonrası değerler karşılaştırıldığında depresyon skorları açısından anlamlı fark saptanmamıştır.

Bu çalışmanın kısıtlılıkları; prospektif olmaması, hasta sayısının az olması, izlem süresinin kısa olması ve çalışmanın primer sonlanım noktasının kırık ve kemik mineral yoğunluğu verileri olmamasıdır. Bununla birlikte ülkemizde teriparatid tedavisinin ağrı, yaşam kalitesi, depresyon ve biyokimyasal parametreler üzerine etkisinin araştırıldığı başka bir çalışmaya rastlanmadı. Bu çalışma, teriparatid tedavisinin ülkemizdeki hasta populasyonu üzerinde belirtilen parametrelerce değerlendirilen ilk çalışma olması ve bu konuda yapılacak çalışmalar için yol gösterici olması açısından önemlidir.

Sonuç olarak; şiddetli postmenopozal kadın hastalarda teriparatid tedavisi ile 6. ayın sonunda sırt ağrı düzeyi, yaşam kalitesi ağrı alt parametresi ve total değerlendirmesi açısından iyileşme saptanır iken, depresyon düzeyi ve biyokimya parametreleri açısından anlamIı bir değiş̧iklik gözlenmedi. Bu konuda daha büyük hasta gruplarıyla, kemik mineral yoğunluğu değişimlerinin de değerlendirildiği, daha uzun izlem süresi olan klinik çalışmalara ihtiyaç vardır.

\section{Kaynaklar}

1. Papaioannou A, Joseph L, loannidis G, Berger C, Anastassiades T, Brown JP, et al. Risk factors associated with incident clinical vertebral and nonvertebral fractures in postmenopausal women: the Canadian Multicentre Osteoporosis Study (CaMos). Osteoporos Int 2005;16:568-78.

2. Lombardi I, Oliveria L, Monteiro CR, Confessor YQ, Barros TL, Natour J. Evaluation of physical capacity and quality of life in osteoporotic women. Osteoporos Int 2004;15:80-5.

3. Lips P, van Schoor NM. Quality of life in patients with osteoporosis. Osteoporosis Int 2005; 16:447-55.

4. Akyüz G. Osteoporozda ağrı ve yaşam kalitesi. In: Kutsal YG, editör. Modern Tip Seminerleri 19: Osteoporoz. Ankara, Güneş Kitabevi; 2001. p. 204-11.

5. Hochberg MC, Greenspan S, Wasnich RD, Miller P, Thompson DE, Ross PD. Changes in bone density and turnover explain the reductions in incidence of nonvertebral fractures that occur during treatment with antiresorptive agents. J Clin Endocrinol Metab 2002;87:1586-92.

6. Human KL, Lane NE. Parathyroid hormone uptade. Rheum Dis Clin North Am 2006;32:703-19.

7. Rubin MR, Cosman F, Lindsay R, Bilezikian JP. The anabolic effects of parathyroid hormone. Osteoporos Int 2002;13:267-77.

8. Dobnig H, Turner RT. Evidence that intermittent treatment with parathyroid hormone increases bone formation in adult rats by activation of bone lining cells. Endocrinology 1995;136:3632-8.

9. Osteoporoz. In: Tan AA, çeviri editörü. Türkiye Klinikleri Seri no:100. Ankara, Ortadoğu Reklam Tanıtım ve Yayınclık A.Ş.; 2006. p.148-50.

10. Bodenner D, Redman C, Riggs A. Teriparatide in the management of osteoporosis. Clin Interv Aging 2007;2:499-507.

11. Genant HK, Wu CY, van Kuijk C, Nevitt MC. Vertebral fracture assessment using a semiquantitative technique. J Bone Miner Res 1993;8:1137-48.

12. The WHO Study Group. Assessment of fracture risk and its application to screening for postmenopausal osteoporosis. Geneva. World Health Organization, 1994.

13. Kocyiğit H, Gulseren S, Erol A, Hizli N, Memiş A. The reliability and validity of the Turkish version of Quality of Life Questionnaire of the European Foundation for Osteoporosis (QUALEFFO). Clin Rheumatol $2003: 22: 18-23$
14. Beck AT, Ward CH, Mendelson M, Mock J, Erbaugh J. An inventory for measuring depression. Arch Gen Psychiatry 1961;4:561-71.

15. Lips P, van Schoor NM. Quality of life in patients with osteoporosis. Osteoporos Int 2005;16:447-55.

16. Crans GG, Silverman SL, Genant HK, Glass EV, Krege JH. Association of severe vertebral fractures with reduced quality of life. Arthritis Rheum 2004;50:4028-34.

17. Romagnoli E, Carnevale V, Nofroni I, D'Erasmo E, Paglia F, De Geronimo S, et al. Quality of life in ambulatory postmenopausal women: the impact of reduced bone mineral density and subclinic vertebral fractures. Osteoporos Int 2004;15:975-80.

18. Özkul I. Osteoporoz tedavisinde paratiroid hormon. Osteoporoz dünyasından 2002;8:42-8.

19. Rubin MR, Comsan F, Lindsay R, Bilezikian JP. The anabolic effects of parathroid hormone. Osteoporos Int 2002;13:267-77.

20. Nau AN, Ali SH, Sawka AM, Thabane L, Papaioannou A, Gafni A, et al. Improvement in health-related quality of life in osteoporosis patients treated with teriparatide. BMC Musculoskelet Disord 2008;9:151.

21. Langdahl BL, Gerald R, Jakop F, Karras D, Ljunggren O, Lems WF, et al. Reduction in fracture rate and back pain and increased quality of life in postmenopausal women treated with teriparatide: 18-month data from the european forsteo observational study (EFOS). Calcif Tissue Int 2009;85:484-93.

22. Genant HK, Halse J, Briney WG, Xie L, Glass EV, Krege JH. The effects of teriparatide on the incidence of back pain in postmenopausal women with osteoporosis. Curr Med Res Opin 2005;21:1027-34.

23. Newitt MC, Chen P, Kiel DP, Reginster JY, Dore RK, Zanchetta JR, et al. Reduction in the risk of developing back pain persist at least 30 months after discontinuation of teriparatide treatment: a metaanalysis. Osteoporos Int 2006;17:1630-7.

24. Neer RM, Arnaud CD, Zanchetta JR, Prince R, Gaich GA, Reginster JY, et al. Effect of parathyroid hormone (1-34) on fractures and bone mineral density in postmenopausal women with osteoporosis. $\mathrm{N}$ Engl J Med 2001;344:1434-41.

25. Orwoll ES, Scheele WH, Paul S, Adami S, Syversen U, Diez-Perez A, et al. The effect of teriparatide [human parathyroid hormone (1-34)] therapy on bone density in men with osteoporosis. J Bone Miner Res 2003;18:9-17.

26. Body JJ, Gaich GA, Scheele WH, Kulkarni PM, Miller PD, Peretz A, et al. A randomized double-blind trial to compare the efficacy of teriparatide [recombinant human parathyroid hormone (1-34)] with alendronate in postmenopausal women with osteoporosis. J Clin Endocrinol Metab 2002;87:4528-35.

27. Ste-Marie LG, Schwartz SL, Hossain AM, Desaiah D, Gaich GA. Effect of teriparatide [rh parathyroid hormone (1-34)] on bone density when given to postmenopausal women receiving hormone replacement therapy. J Bone Miner Res 2006;21:283-91.

28. Gold DT, Patnos BS, Masica DN, Misurski DA, Marcus R. Initial experience with teriparatide in the United States. Curr Med Res Opin 2006;22:703-8.

29. Canalis E, Giustina A, Bilezikian JP. Mechanism of anabolic therapies for osteoporosis. N Engl J Med 2007;357:905-16.

30. Vrkljan M, Thaller V, Lovricevic I, Gacina P, Resetic J, Bekic M, et al. Depressive disorder as possible risk factor of osteoporosis. Coll Antrropol 2001;25:485-92.

31. Lyles KW. Osteoporosis and depression: shedding more light upon a complex relationship. Journal of the American Geriatrics Society 2001;49:827-8.

32. Coelho R, Silva C, Maia A, Prata J, Barros H. Bone mineral density and depression: a community study in women. J Psychosom Res 1999;46:29-35.

33. Gold DT. The clinical impact of vertebral fracture: quality of life in women with osteoporosis. Bone 1996;18:185-9.

34. Saygı EK, Özkök Ö, Kaya Ü, Akyüz G. Rizedronat tedavisinin ağrı ve yaşam kalitesi üzerine etkileri. Osteoporoz Dünyasından 2009;15:34-7. 